\title{
The Research on Food Waste Pre-Treatment Technology for Incineration in Malaysia
}

\author{
Ahmad Faizal Zamli ${ }^{1,2 *}$, W.M.F. Wan Mahmood ${ }^{1}$, W.A.W. Ghopa ${ }^{1}$, M.T. Lim ${ }^{2}$ \\ ${ }^{1}$ Department of Mechanical and Manufacturing Engineering, Faculty of Engineering and Built Environment, Universiti Kebangsaan Malaysia (UKM), \\ 43600 UKM Bangi, Selangor, Malaysia \\ ${ }^{2}$ Centre of Bioenergy \& Sustainability, Renewable Energy \& Green technology, Generation and Environment, TNB Research Sdn. Bhd., 43000 Kajang, \\ Selangor, Malaysia
}

Received: 09/08/2020

Accepted: 21/10/2020

Published: 20/03/2021

\begin{abstract}
Food waste and food loss are used to describe materials that are actually produced for consumption, but are discarded, lost, degraded or contaminated. Food waste (FW) is one of the main parts of municipal solid waste. Landfill is not preferable when compared with other types of waste handling method. It has been reported that the impact of landfill on climate change can be ten times higher than other waste handling methods. However, most FW end up in landfills. This paper reviewed the performance of several food waste pre-treatment technologies to convert FW into feedstock for incinerators/boilers in terms of electrical power generation purposes. The performance of food waste pretreatment methods and their products were extensively discussed and compared in this paper in terms of calorific value, energy density, and compound reduction, which later directly corresponded with the energy, environmental, and economic factors for the sustainability of future renewable power generation.
\end{abstract}

Keywords: Alternative fuel; bioenergy; deep drying; fuel pre-treatment; alternative fuel; waste to energy; energy densification; thermochemical process

\section{Introduction}

One third of the food produced globally are wasted, which amounts to about 1.3 billion tonnes per year (1). Food waste (FW) and food loss (FL) are used to describe materials that are actually produced for consumption, but are discarded, lost, degraded or contaminated (2). In 1981, according to the Food and Agriculture Organisation of the United Nations (FAO), the definition of FW includes the post-harvest period of food when in possession of final consumers (3). Gustavsson et al. came up with the same definition, however, they included the food supply chain (FSC) that contains a five-system boundary. It comprises agriculture production, post-harvest handling and storage, processing, distribution, and consumption (1). Malaysia approximately produces more than 15,000 tonnes of FW daily as reported in 2018 (4). In 2006, 93.5\% of the municipal solid waste (MSW) in Malaysia were sent to landfills or open dumpsites and only $5.5 \%$ were recycled and $1 \%$ was composted (5). In the Waste Management Association of Malaysia (WMAM) Conference 2019 (6), the rate of recycling in Malaysia had drastically risen to $28.06 \%$ in 2018. Nevertheless, in the same year, 13,830,014 tonnes of waste were generated in the country. The waste had doubled from 19,100 tonnes per day (5) or 6,971,500 tonnes per year in 2006. Several studies found that landfills are not preferable when compared with other types of waste handling method (7-12). Landfills are one of the factors that contribute towards climate change due to greenhouse gas ${ }^{1}(\mathrm{GHG})$ emission. It is reported that the impact of landfill on climate change can be ten times higher than other waste handling methods (13). In Asia, especially in Malaysia, FW is one of the main components of MSW. Most FW end up in landfills. Landfills cause gas emission problems of carbon dioxide $(\mathrm{CO} 2)$ and methane $(\mathrm{CH} 4)(14,15)$. Methane gas is produced through aerobic and anaerobic decomposition of solid waste and is a more potent GHG than carbon dioxide (7). Currently, FW recovery from MSW is relatively low. FW is one of the main parts of municipal solid waste (MSW). With its abundant source, the potential for this waste to become power generation feedstock in Malaysia is less explored. Most of the time, FW is not properly sorted and has high moisture content. These mixed wastes contaminate other MSW components and recyclable materials in them. Dewatering and drying are very important for achieving high energy recovery from FW and thermal drying is still a main method for FW drying (16). A correct pre-treatment method of FW can convert it into feedstock for incinerators or boilers. Incinerators are more reliable in volume and contribute towards mass reduction of waste in a shorter duration.

*Corresponding author: Ahmad Faizal Zamli, Centre of Bioenergy \& Sustainability, Renewable Energy \& Green technology, Generation and Environment, TNB Research Sdn. Bhd., 43000 Kajang, Selangor, Malaysia. E-mail: faizal.zamli@tnb.com.my 
This paper reviews the performance of several FW pretreatment technologies to convert FW into feedstock for incinerators/boilers. The performance of $\mathrm{FW}$ pre-treatment method and its products are discussed in this paper in terms of calorific value, energy density, compounds/elemental reduction and etc. for sustainable future renewable power generation.

\subsection{Municipal Solid Waste, Food Waste, And Waste To Energy Incineration}

The MSW generation in Peninsular Malaysia has been increasing since 2001 (8). Kuala Lumpur is the top city in Malaysia that produces the most MSW and in 2013, it produced 3000 tonnes/day of MSW (8). Table 1 below shows the data of population and generation of MSW for some countries. It is observed that the amount of MSW generated daily is directly proportional with the population living in the town/country. MSW generation also depends on a person's diet and the waste management system's condition in these certain areas.

Table 1: The trends of population and the MSW generation

\begin{tabular}{lllll}
\hline $\begin{array}{l}\text { Town/ } \\
\text { Country }\end{array}$ & Country & $\begin{array}{l}\text { MSW } \\
\text { generated }\end{array}$ & Population & Region \\
\hline $\begin{array}{l}\text { Kuala } \\
\text { Lumpur } \\
(8)\end{array}$ & Malaysia & $\begin{array}{l}3000 \\
\text { tonnes/day }\end{array}$ & $5,809,953$ & $\begin{array}{l}\text { South } \\
\text { East } \\
\text { Asia }\end{array}$ \\
& & & & \\
Rasht (17) & Iran & $\begin{array}{l}0.9-1.0 \\
\text { tonnes/day }\end{array}$ & 700,000 & $\begin{array}{l}\text { Middle } \\
\text { East }\end{array}$ \\
& & & & \\
Indonesia & Indonesia & $\begin{array}{l}190,000 \\
\text { tonnes/day }\end{array}$ & $253,000,000$ & $\begin{array}{l}\text { South } \\
\text { East } \\
\text { Asia }\end{array}$ \\
& & & & \\
\hline
\end{tabular}

Table 2: MSW composition for some country

\begin{tabular}{|c|c|c|c|c|c|c|c|}
\hline $\begin{array}{l}\text { Town/ } \\
\text { Country }\end{array}$ & 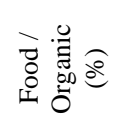 & 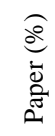 & 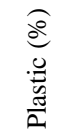 & 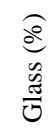 & $\frac{\widehat{\overparen{g}}}{\sum^{\frac{\pi}{2}}}$ & 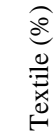 & $\frac{\underbrace{2}_{0}}{\stackrel{0}{0}}$ \\
\hline $\begin{array}{l}\text { Malaysia } \\
(8)(19)\end{array}$ & $45-48$ & $\begin{array}{l}7- \\
15\end{array}$ & $\begin{array}{l}14- \\
24\end{array}$ & 3 & 6 & - & $\begin{array}{l}15 \\
- \\
23\end{array}$ \\
\hline $\begin{array}{l}\text { South Asia } \\
(20)\end{array}$ & 50 & 4 & 7 & 1 & 1 & - & 37 \\
\hline $\begin{array}{l}\text { *OECD } \\
(20) \\
\text { Latin }\end{array}$ & 27 & 32 & 11 & 7 & 6 & - & 17 \\
\hline $\begin{array}{l}\text { America } \\
(20)\end{array}$ & 54 & 16 & 12 & 4 & 2 & - & 12 \\
\hline $\begin{array}{l}\text { Estonia } \\
(21)\end{array}$ & 29 & $\begin{array}{l}16 . \\
5\end{array}$ & 17.8 & 6.8 & 2.9 & 4.8 & $\begin{array}{l}22 . \\
2\end{array}$ \\
\hline $\begin{array}{l}\text { Wenzhou, } \\
\text { China (22) }\end{array}$ & 44.7 & 1.7 & 23.9 & 1.3 & 1 & - & $\begin{array}{l}27 . \\
4\end{array}$ \\
\hline
\end{tabular}

*Organization for Economic Cooperation and Development (OECD)

The data from Table 2 above show the composition of MSW in several countries. In South Asia, for example, it is observed that FW is almost half of the MSW wastes generated. The range for FW in Malaysia's MSW is from $40 \%$ to $50 \%$ (19). FW normally comprises high water content with a low heating value (23). Therefore, a pre-treatment method is needed to enhance the properties of FW so that it can become a good feedstock for incinerators. This unrecoverable source such as FW needs to be treated as soon as possible since most of the time, the food waste contains organic materials and will undergo the fermentation process after a short interval of time with exposure to the surrounding air.

FW can be alternatively recycled into pelletised poultry food or pet food. Besides, these food wastes can be converted into biogas; however, they require a low contamination condition and the process is very delicate. Most of the time, MSW mixed with FW cannot be recycled anymore due to high impurity, bad odour, and high cost of waste sorting, among others. The age of FW usually determines the method of waste to be treated. Sorted fresh FW can be used as feedstock for biogas reactors. Older versions of FW are more suitable to be processed into fertilisers. Normal incinerators can handle all types of FW. However, untreated or wet FW can become a problem with steam production in terms of heat and pressure fluctuation. These conditions happen because there is a big range of gap of calorific value $(\mathrm{CV})$ in the untreated $\mathrm{FW}$. Proper pre-treatment is needed for FW so that this source can become a game changer in power generation using MSW.

A study in Singapore found that on average, the local residents generated $118 \mathrm{~g}$ of table $\mathrm{FW}$ and $91 \mathrm{~g}$ of kitchen FW per person for each meal. A total of 1,000 tonnes of FW with $16 \%$ impurities are generated daily in Singapore (23). In Malaysia, it is reported that in 2011 and 2018, 20,000 tonnes (24) and 37,890 tonnes of solid waste were generated each day and almost half of them were FW. Abundant solid wastes generated every day require an expensive handling cost. In Malaysia, local authorities spend up to $60 \%$ of their annual budget on waste management. This costs Malaysia between RM110 to RM130 to collect and dispose one tonne of garbage [8] and this does not yet include the land requisition cost. Other research discovered that $70 \%$ of the total cost of waste management in Malaysia are spent on the collection of waste (25).

Asian countries such as China and Singapore are operating waste-to-energy (WTE) incineration plants to convert their waste into energy. Gasification and anaerobic digestion plants use FW as feedstock; however, they are still under research and development. It has been reported that gasification and anaerobic digestion $(\mathrm{AD})$ can give better performance in terms of larger environmental benefits (23) than incineration. The problems with these systems are that these technologies are not ready or robust for large-scale commercialization. The shutdown of an AD plant in Singapore in 2011 is an example of the system's failure (26).

On the other hand, incineration plants have increased rapidly in the last 50 years for both China and Singapore. The plan to increase incineration plants in both countries shows that the demand for this type of WTE is still huge $(22,26)$. However, as reported in 2015, the waste separation in China was poorly executed and no pre-treatment was done to the waste prior to WTE incineration (22). With more wastes being generated each and every day, waste incineration is the best option to reduce waste. For example, incineration can reduce up to $70 \%$ of volume and $80 \%$ mass (27) of the waste. This technology has vastly improved over time (9). As mentioned before, it is not suitable to utilize raw $\mathrm{FW}$ as fuel in incinerators because of its high moisture content. Furthermore, the combustion of fuel with high moisture content such as FW is not economical. For example, the National 
Environment Agency (NEA) in Singapore has a plan to remove eatery FW from incineration to $\mathrm{AD}(23)$. This could be prevented if FW in the MSW is pre-treated using pellet technology before the incineration process. Pre-treatment of FW increases calorific value, making FW a more suitable fuel for incinerators. The pretreatment can reduce unwanted chemicals as well as the moisture content. This would help to increase the incinerator system's efficiency in the future.

This study looks into the application of seven FW pretreatment technologies and its product characteristic based on the literature study. The pre-treatment data from literature are analysed from the point of view of economic, environmental and energy which represented by energy density, unwanted compounds/ chemical reduction and calorific value. These data are ranked using the Weighted Factor Rating to select the best FW pre-treatment practices for the incineration application.

\section{Food Waste Pre-Treatment Technology for Power Generation}

FW can become better fuel for the incineration process with the correct pre-treatment method. Other problems related to FW incineration is its emission products are derived from chemical reaction that comes from the elements and compounds inside the FW. Unwanted elements and compounds from the FW can be minimized after the pre-treatment is done. The best FW pretreatment method is the one that is capable of economically minimizing harmful emissions, increasing calorific value, and increasing energy density of the treated FW. This subtopic will discuss several FW pre-treatment technologies to convert FW into feedstock for thermochemical oxidizers such as incinerator, boiler furnace, and gasifier. Table 3 shows the food waste pre-treatment methods and their product calorific value.

\subsection{Torrefaction}

Literally, torrefaction is a French word that can be directly translated as roast or grill and it is likely used in the past as a process for coffee production. Torrefaction is a technology to convert $\mathrm{FW}$ into char by exposing $\mathrm{FW}$ to high temperature without the presence of oxygen. During torrefaction, moisture content is reduced as unbound moisture is eliminated through the evaporation process with increased temperature ranging from 200 ${ }^{\circ} \mathrm{C}$ to $300{ }^{\circ} \mathrm{C}(11)$. The normal biomass torrefaction temperature is around $300{ }^{\circ} \mathrm{C}$; higher thermal pre-treatment temperature is referred as pyrolysis (29). With an increase in temperature from $210{ }^{\circ} \mathrm{C}$ to $250{ }^{\circ} \mathrm{C}$, light volatiles like $\mathrm{CO}_{2}, \mathrm{CO}$, and $\mathrm{H}_{2} \mathrm{O}$ are emitted (38). These volatile matters are produced due to the degradation of hemicellulose and light aliphatic compounds from carbohydrates, which are more sensitive to temperature than other biomass components (11).

Heavier volatiles are reduced as gases during the reduction of cellulose, protein, and carbohydrate compounds as temperature is increased to $300{ }^{\circ} \mathrm{C}$. Methane, formic acid, acetic acid, and aromatic are some examples of the gases produced in this stage $(38,39)$. The carbon content and energy density in the biochar products are enhanced, which is directly linked with the increase in calorific value of the biochar products $(11,28-30)$. It is observed that the treated FW's lifespan increases as compared to raw FW.
Table 3: MSW composition for some country

\begin{tabular}{|c|c|c|c|c|c|}
\hline No & Fuel type & Pre-treatment & Product & $\begin{array}{l}\mathrm{CV} \\
(\mathrm{MJ} / \mathrm{kg})\end{array}$ & $\begin{array}{l}\text { MC } \\
(\%)\end{array}$ \\
\hline 1 & Coal (11) & Raw & $\begin{array}{l}\text { Anglo } \\
\text { Mafube } \\
\text { bitumin } \\
\text { ous coal }\end{array}$ & 25.2 & NR \\
\hline \multirow{2}{*}{2} & \multirow{2}{*}{ FW (11) } & \multirow{2}{*}{ Torrefaction } & \multirow{2}{*}{ Biochar } & $26.15 \&$ & NR \\
\hline & & & & $\begin{array}{l}19.76 \\
\text { (Raw) }\end{array}$ & NR \\
\hline 3 & $\begin{array}{l}\text { Landfill } \\
\text { FW (28) }\end{array}$ & Torrefaction & Biochar & $\begin{array}{l}17.45 \text { to } \\
28.42 \\
19.5 \text { to }\end{array}$ & NR \\
\hline 4 & $\mathrm{FW}(29)$ & Torrefaction & Biochar & $\begin{array}{l}22.25 \& \\
19.52 \\
\text { (Raw) }\end{array}$ & NR \\
\hline 5 & $\begin{array}{l}\text { FW(starch } \\
\text { y, rice) } \\
(30)\end{array}$ & $\begin{array}{l}\text { Steam } \\
\text { Torrefaction }\end{array}$ & Biochar & $\begin{array}{l}18.44 \text { to } \\
27.44 \& \\
18.08 \\
\text { (Raw) }\end{array}$ & NR \\
\hline \multirow{2}{*}{6} & \multirow{2}{*}{ FW (16) } & \multirow{2}{*}{$\begin{array}{l}\text { Air and } \\
\text { thermally } \\
\text { assisted bio- } \\
\text { drying }\end{array}$} & \multirow{2}{*}{ FW } & $12.86 \&$ & 9.95 \\
\hline & & & & $\begin{array}{l}4.3 \text { (Raw } \\
\text { wet) }\end{array}$ & $\begin{array}{l}63.2 \\
1\end{array}$ \\
\hline 7 & FW (31) & $\begin{array}{l}\text { Pre-treat with } \\
\text { enzyme \& } \\
\text { Hydro } \\
\text { thermal } \\
\text { carbonization } \\
\text { (HTC) }\end{array}$ & $\begin{array}{l}\text { Hydro- } \\
\text { char }\end{array}$ & $\begin{array}{l}17.4 \text { to } \\
26.9\end{array}$ & NR \\
\hline 8 & $\begin{array}{l}\text { Restaurant } \\
\text { FW (31) }\end{array}$ & HTC & $\begin{array}{l}\text { Hydro- } \\
\text { char }\end{array}$ & 15 to 21.7 & NR \\
\hline 9 & FW (32) & HTC & $\begin{array}{l}\text { Hydro- } \\
\text { char }\end{array}$ & $\begin{array}{l}17.85 \text { to } \\
31.73\end{array}$ & NR \\
\hline 10 & FW (32) & Raw & FW & 17.85 & NR \\
\hline 11 & $\begin{array}{l}\text { Restaurant } \\
\text { FW (33) }\end{array}$ & & $\begin{array}{l}\text { Hydro- } \\
\text { char }\end{array}$ & 33.57 & NR \\
\hline 12 & MSW (34) & $\begin{array}{l}\text { RDF (8-10\% } \\
\text { bio-waste) }\end{array}$ & Loose & 6 to 15 & NR \\
\hline 13 & MSW(35) & $\begin{array}{l}\text { RDF from } \\
\text { household \& } \\
\text { industrial } \\
\text { sources. }\end{array}$ & NR & 12 to 21 & $\begin{array}{l}3 \text { to } \\
35\end{array}$ \\
\hline 14 & FW & Autoclave & Fibre & NR & NR \\
\hline 15 & $\begin{array}{l}\text { Vegetables } \\
\text { and leafy } \\
\text { FW (36) }\end{array}$ & Autoclave & Fibre & $\begin{array}{l}11.7 \text { to } \\
15.7 \\
\text { (Treated) }\end{array}$ & NR \\
\hline 16 & $\begin{array}{l}\text { MSW } \\
\text { woody } \\
\text { biomass } \\
\text { and agri- } \\
\text { food waste } \\
(37)\end{array}$ & Pelletization & Pellet & 19.5 & NR \\
\hline
\end{tabular}

Overall, torrefaction technology has big potential to pre-treat FW in the future since FW is generated every day and still increases. The main issues that need further consideration in the torrefaction of $\mathrm{FW}$ are to reduce the process time, reduce ash content, and increase the capacity with efficient use of energy. It is suggested that solar integration to the torrefier system can further increase the torrefier technology value. 


\subsection{Autoclaving}

Autoclaving is a process that involves steam processing in a vessel under the action of pressure (40). This process is done to FW to enhance the quality of the waste in terms of its potential to produce better gas from biogas or gasification processes or produce better fuel for combustion or other types of waste management process. Moreover, this process sterilizes FW that decontaminates other wastes and neutralizes odor compounds. Sterilization of FW also enhances the subsequent application of recovered wastes. Autoclaving of biodegradable and organic wastes such as FW and paper converts them into a fiber-like material (36).

An example of autoclaving process is using $2-3 \mathrm{~kg}$ of sorted and dried FW in a $24 \mathrm{~L}$ tank filled with water and treated at a temperature range of $121^{\circ} \mathrm{C}$ to $127^{\circ} \mathrm{C}$ and $17 \mathrm{psi}$ to $21 \mathrm{psi}(1.17$ bar to 1.45 bar) in an autoclave reactor for 35 to 60 minutes (40). This study found that autoclaved FW had lower heavy metal content and was within the range of compost standard. Another study used injected steam and $45.9 \mathrm{~kg}$ of vegetables and leafy fruit waste from supermarkets in a $530 \mathrm{~L}$ rotary $(7 \mathrm{rpm})$ autoclaved reactor at temperatures of $408 \mathrm{~K}\left(134.9^{\circ} \mathrm{C}\right), 428 \mathrm{~K}\left(154.9^{\circ} \mathrm{C}\right)$, and $438 \mathrm{~K}\left(164.9^{\circ} \mathrm{C}\right)$ and $3,6,7 \mathrm{~kg} / \mathrm{cm}^{2}$ or approximately around 3,6 and 7 bar for 15 and 60 minutes (36). This autoclaved food waste showed reduced calorific value, volume reduction, and increase in product density.

This study also discovered that the fiber content of hemicellulose, cellulose, and lignin fluctuated and it is suggested that the autoclaving process had altered the fiber in the samples. Further study is needed to increase the knowledge and fine tune the system to have a better perspective of the real potential in treating FW using the autoclaving method.

\subsection{Thermally assisted bio-drying}

Bio-drying is a process to reduce excessive water in FW. FW consists of high biology waste materials that are suitable for the bio-drying process. Solid fuel with higher energy content is obtained at the end of the bio-drying process. Bio-drying method uses energy produced from microbial degradation in the FW to heat up water with the assistance of forced aeration (16). This condition increases water evaporation and stimulates microbial degradability. It is found that staged heating acclimation can obtain a superior thermophilic inoculum with high metabolic activity and microbial consortia. An extremely high metabolic activity is obtained during the thermally assisted bio-drying process, which is greatly higher than conventional bio-drying (16).

Jiao Ma et al. conducted thermally assisted bio-drying, which operated at temperatures of $50{ }^{\circ} \mathrm{C}$ to $60{ }^{\circ} \mathrm{C}$ using 1.2 to 2.2 L containers filled with 500 to $1000 \mathrm{~g} \mathrm{FW}$ in 5 days' reaction time (16). At the high airflow rate and high temperature condition, water vapor is taken out of the matrix in a shorter time. The remaining solid waste can become refuse-derived fuel (RDF), which is a carbon neutral fuel and a renewable alternative source to fossil fuel. The time consumption for the whole process to complete can become a main issue in the thermally assisted biodrying process. Further study can be done to reduce the process time, increase the calorific value content, and increase the capacity of the process. FW decomposition method that converts FW into fertilisers adapts an almost similar concept with thermally assisted bio-drying.

\subsection{Hydrothermal carbonization}

Hydrothermal carbonization (HTC) is another thermochemical pre-treatment method that can be used to convert FW into fuel. HTC is able to reduce the unwanted high moisture content from FW. HTC is a pre-treatment process that is applied to organic waste at certain operating condition setting, temperature range of $200-350{ }^{\circ} \mathrm{C}$, and process duration within 0.2 to $120 \mathrm{~h} \mathrm{(41).} \mathrm{The} \mathrm{hydro-char} \mathrm{products} \mathrm{from} \mathrm{this} \mathrm{thermal} \mathrm{pre-}$ treatment method are with high carbon and energy content.

Besides, a study reported the positive energy balances on the HTC pre-treatment of FW (33). The energy content may be influenced by the presence of packaging materials that are usually found together with the recovered solids. This study compared the HTC energy content of several samples from pure FW and the FW with packaging materials. The level of energy content of recovered solids from FW with packaging materials showed a reduction when compared with the pure FW. This may due to the low energetic retention, which is associated with the packaging materials (33).

Previous research found that hydro-char is possibly generated by two major reaction pathways (42). One of the methods is the hydro-char formation via direct solid-solid conversion, which mainly follows the path of de-volatilization, intramolecular condensation, dehydration, and decarboxylation reaction. The next possible reaction is the conversion of intermediate products in the aqueous phase, which experiences hydrolysis, dehydration, decarboxylation, polymerization, and aromatization. HTC resulted in the reduction of volatile matters (43) and it is found that hydro-chars from the HTC process can increase the FW energy density and calorific value.

\subsection{Leaching technology}

Leaching is another type of pre-treatment method that has been proven to treat biomass [44]. Leaching, which uses water, can be used to reduce some of the FW's unwanted elements or compounds such as heavy metals, alkali metals, contamination during handling, for instance. The application of water-based pretreatment for waste, especially $\mathrm{FW}$, has high potential to be explored. The objective of the pre-treatment is to improve the FW calorific value and to reduce the unwanted compounds inside the FW in order to prevent the formation of slag, emission of toxic gases, and smell pollution.

The FW leaching requires additional energy for the drying process. Leaching improves the FW properties such as lower moisture content, cleaner, less odor, and ability to be kept longer. The reduction of unwanted elements/compounds in the fuel may produce cleaner gas emission. The water-washing technology is known to assist the reduction of alkali metals in bio materials $(44,45)$. If these alkali metals are not reduced, they will devolatilize, nucleate, and condense to form hydroxide, chloride, and sulphate compounds (46-49).

Slag reduction is expected after the FW leaching pretreatment method. The washing process during the leaching pretreatment will readjust and modify the elemental composition inside the FW. Alternatively, slag can be controlled by mixing known fuel composition with other types of fuel or additive to balance the slag formation element/compound and this method is called fuel blending. Leaching can be used together with fuel blending to maximize the pre-treated product potential. 


\subsection{Refuse-Derived Fuel (RDF) and Solid Recovered Fuel (SRF)}

Fundamentally, RDF is similar to SRF; however, they differ in terms of source, constituents, and pre-processing included during the process (9). RDF is composed of wastes generated from domestic and business sectors that primarily involve biodegradable and plastics, while SRF is a much more homogenous waste-derived fuel from MSW and commercial waste that has undergone an additional process to improve its quality and calorific value and meet the European CEN/TC 343 standards (50). SRF is standardized as a type of fuel that is nonhazardous and complies with European standard EN15359. This solid fuel requires the producer to specify and classify SRF by specific net calorific value, grain size, chlorine, mercury, and heavy metal content (34) in the fuel. The fuel specification is mandatory for several other properties, including all heavy metal content as mentioned in the Industrial Emissions Directive (IED, UK) and a declaration of conformity has to be issued.

Both fuels are suitable to become feedstock in cement furnaces and boilers for co-combustion (20). RDF and SRF use sieving and sorting in the beginning of the process to reduce the moisture content of MSW and to separate recyclable or directly burnt waste. RDF and SRF are generally a better option than traditional landfill in terms of environmental sustainability. A very large $\mathrm{CV}$ range is expected since it is the combination of many wastes and a fluctuation of $\mathrm{CV}$ and gas emission is understandable. It is suggested that organic and inorganic wastes are separated at the beginning of the process to understand their composition, gas emissions, and other combustion products. Better environmental impact can be achieved when the power production plant uses waste from RDF and SRF. The reduction of chemical pollutants inside the MSW by sorting or other processes can be integrated to produce better fuel for a cleaner environment. This would give more public acceptance of the realization of MSW as a reliable source for incineration power plants.

RDF and SRF fuel are generally products of processing waste derived from MSW and FW. Processing of FW using SRF or RDF can improve the FW capability to become better fuel in the future. Table 4 below shows the classification of RDF by the American Society of Mechanical Engineers (ASME).

\subsection{Palletization technology}

Palletization technology can be used to assist the improvement of FW calorific value. This technology can enhance the properties of FW and increase its value by removing unwanted moisture, reducing the porosity inside the FW, and significantly increasing the FW density. Palletization technology is known to assist the densification of biomass, which will also enhance mechanical durability (51). The moisture content reduction less than $10 \%$ is better because Malaysia has high FW moisture content. Uniform moisture content from FW pellet is needed so that the incinerator temperature and pressure do not fluctuate during steam production. Incineration normally requires low moisture content and high calorific value feedstock. The higher the energy density, the better with lesser maintenance needed inside the incinerator. Higher energy density from pelletized FW can contribute towards higher thermal heating for steam production. Pelletizing can become one part of several combinations of FW pre-treatment system. The pellet formed during high pressure compaction of $\mathrm{FW}$ into the metal die is applied inside the pellet machine. Good pellet formation requires suitable moisture content and binder inside the feedstock. During the palletization process, heat will be generated during the compaction process resulted from the friction between the metal roller, metal die, and feedstock. The fiber structure inside the organic waste such as lignin can act as a natural binder (52) during the pellet production process. Pellet mechanical durability and its quality depend on the densification pressure, temperature, lignin, and starch content (51).

Table 4: Classification of RDF by ASME 828:1981

\begin{tabular}{lll}
\hline No & $\begin{array}{l}\text { RDF } \\
\text { types }\end{array}$ & Specification \\
&
\end{tabular}

$1 \quad$ RDF 1 Raw waste or with minimal processing

2 RDF 2 Waste processed into coarse particles with no separation metals in a way that $95 \%$ by weight of 6-inch square mesh sieve pass.

3 RDF 3 Processed fuel derived from waste by separating the metals, glass, and other inorganic materials. The material in a way that a 2 inch square mesh sieve passes.

4 RDF 4 Combustible waste components in powder form and $95 \%$ by weight of 0.035 inch square mesh sieve pass.

5 RDF 5 Flammable waste extruded sections (compressed) in the form of pellets, cubes, briquettes, or similar forms. Due to the numerous advantages of portability and storage, and the ability to coordinate with a variety of combustion systems in developing

6 RDF 6 The combustible waste in liquid form is processed

7 RDF 7 The combustible waste gas is processed to form.

\section{Detailed Review of the Pre-Treatment Technologies}

This section will review, compare, and discuss all the pretreatment methods stated in the earlier section. Table 5 below indicates the classification of food waste technology and energy density as well as their assumptions. Table 6 below shows the FW pre-treatment product characteristics and its rank in terms of calorific value, energy density and unwanted chemical reduction. Table 7 below shows the comparison of FW pretreatment method performance for incineration. From Table 7 above, all FW pretreatment methods are rated in terms of their respective performance in the aspects of energy, economy, and environment. A scale from 1 to 5 is used to rate the pre-treatment methods. The setting for the score is as follows: scale 1 - poor performer, scale 2 - below average, scale 3 - average, scale 4 - above average, and scale 5 - top performer. Three factors had been chosen to compare each pre-treatment method were calorific value, FW energy 
densification, and compound/ chemical reduction. These characteristics are used to determine each pre-treatment performance and its quality to produce better fuel from FW.

Table 5: Energy Density Performance of FW Pre-Treatment

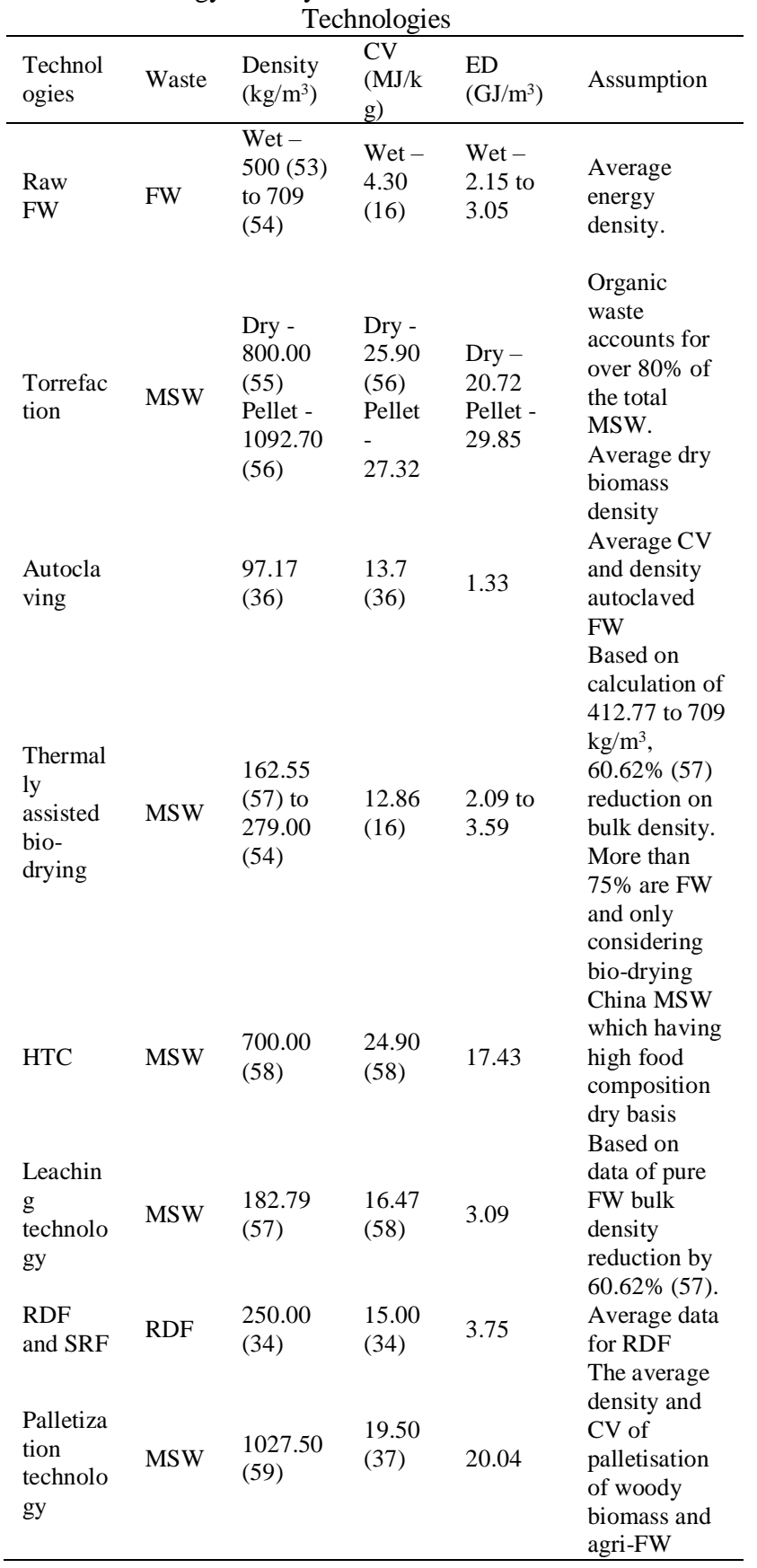

Table 6: The score matrix of treated FW

\begin{tabular}{llll}
\hline Score Rank & $\begin{array}{l}\text { Calorific } \\
\text { Value } \\
\text { (MJ/kg) }\end{array}$ & $\begin{array}{l}\text { ED } \\
\left(\mathrm{GJ} / \mathrm{m}^{3}\right)\end{array}$ & $\begin{array}{l}\text { Acidity, alkali } \\
\text { metal, moisture, } \\
\text { volatile, and } \\
\text { heavy metal } \\
\text { compounds } \\
\text { reduction }\end{array}$ \\
\hline 1 & $<10$ & 0 to 3.09 & $\begin{array}{l}\text { No change } \\
\text { Reduction of } 1 \\
\text { item }\end{array}$ \\
2 & 10 to 14.99 & 3.1 to 7.09 & $\begin{array}{l}\text { Reduction of } 2 \\
\text { items }\end{array}$ \\
3 & 15 to 19.99 & 7.1 to 11.09 & $\begin{array}{l}\text { Reduction of } 3 \\
\text { items } \\
\text { Reduction of } 4 \\
\text { or more items }\end{array}$ \\
\hline 5 & 20 to 24.99 & 11.1 to 15.09 & \\
\hline
\end{tabular}

Table 7 :Comparison of FW Pre-Treatment Method Performance for Incineration

\begin{tabular}{|c|c|c|c|c|}
\hline $\begin{array}{l}\text { Pre- } \\
\text { treatment } \\
\text { method }\end{array}$ & $\begin{array}{l}\text { CV } \\
\text { (Energy) }\end{array}$ & $\begin{array}{l}\text { ED } \\
\text { (Economy) }\end{array}$ & $\begin{array}{l}\text { Acidity, alkali } \\
\text { metal, } \\
\text { moisture, } \\
\text { volatile, and } \\
\text { heavy metal } \\
\text { compound } \\
\text { reduction } \\
\text { (Environment) }\end{array}$ & $\begin{array}{l}\text { Total } \\
\text { score }\end{array}$ \\
\hline Torrefaction & 5 & 5 & 3 & 13 \\
\hline HTC & 5 & 5 & 3 & 13 \\
\hline $\begin{array}{l}\text { Palletisation } \\
\text { technology }\end{array}$ & 3 & 5 & 2 & 10 \\
\hline $\begin{array}{l}\text { Leaching } \\
\text { technology }\end{array}$ & 3 & 1 & 4 & 8 \\
\hline $\begin{array}{l}\text { RDF and } \\
\text { SRF }\end{array}$ & 3 & 2 & 3 & 8 \\
\hline Autoclaving & 2 & 1 & 5 & 8 \\
\hline $\begin{array}{l}\text { Thermally } \\
\text { assisted bio- } \\
\text { drying }\end{array}$ & 2 & 1 & 2 & 5 \\
\hline $\begin{array}{l}\text { Baseline } \\
\text { Raw FW } \\
\text { (Wet) }\end{array}$ & 1 & 1 & 1 & 3 \\
\hline
\end{tabular}

\section{Results and discussion}

Table 7 shows the final result obtained for this study. Overall, torrefaction and HTC pre-treatment product result are the best in terms of their products performance. Both pre-treatment got 13 total score. These pre-treatment methods are the best in terms of calorific value enhancement $(>25 \mathrm{MJ} / \mathrm{kg})$ and $\mathrm{FW}$ energy densification (refer Tables 3, 5, 6, and 7). These pre-treatment methods undergo deep drying and thermochemical processes that reduce the volatile matters and moisture content inside the FW during the char formation, which also enhances the energy densification of FW. FW energy densification is a very important factor for economical transportation and storage costs because these fuel type will not biodegrade over time. Both methods 
scored lower in terms of compound reduction. This was due to the process that involved the reduction of only two compounds (volatile matter and moisture content). Volatiles released in biomass or organic waste commonly includes light hydrocarbons, carbon monoxide $(\mathrm{CO})$, carbon dioxide $\left(\mathrm{CO}_{2}\right)$, hydrogen $\left(\mathrm{H}_{2}\right)$, moisture, and tar (60). Alkali metal-based compounds, such as from potassium $(\mathrm{K})$ and sodium $(\mathrm{Na})$, play a very important role during the slag formation (61) and should be reduced. A study reported that the total amount of potassium and sodium appear to be constant during the torrefaction of wood and this may due to the very small release of alkali metal during the process (62).

Palletization scored the third highest in this study. Palletization of FW could only enhance the energy densification of FW to the maximum and was on par with HTC and torrefaction technology based on Tables 5, 6, and 7. The data also showed the effect of torrefied FW palletization and it was able to increase the energy density to $29.85 \mathrm{GJ} / \mathrm{m}^{3}$. This indicated the combination of these technologies is able to produce better fuel. Normal palletization process only focused on the moisture content reduction from $\mathrm{FW}$; therefore, only one item was reduced using this method. Palletization calorific value was in the middle rank and was not so high as compared to HTC and torrefaction.

Leaching, autoclaving, and RDF and SRF pre-treatment technologies continued the list and shared 8 points. These technologies scored lower in calorific value assessment, which was in the range of 10 to $20 \mathrm{MJ} / \mathrm{kg}$ based on Table 3. On average, autoclaving's CV was the lowest as compared to leaching and RDF and SRF. The autoclaving pre-treatment method reduced the CV significantly during the process. The densification rating for all these pre-treatment was also low because most of the time, these processes only involved the drying process of FW without further chemical processing or palletization. RDF and SRF sorting processes removed high moisture content of MSW from the fuel and limited the heavy metal inside the fuel ( 2 items reduction). Leaching pre-treatment was very effective for organic-based waste in removing alkali metal, such as $\mathrm{K}$ and $\mathrm{Na}$, which were presented as water soluble salt in biomass and organic wastes (62) and also able to reduce FW acidity (63) (the effect of alkali properties of water). Moisture content was also reduced at the end of this process. Autoclaving pre-treatment scored the maximum point for the reduction of four items in the FW. These four items included alkali metal, volatile matter (during thermochemical dehydration), moisture content, and heavy metal. It is known that some heavy metal such as Cadmium (Cd), Copper $(\mathrm{Cu})$, Nickel $(\mathrm{Ni})$, and Zinc $(\mathrm{Zn})$ are contained inside FW and reduced after the autoclaving process (40). This is due to the autoclaving process that uses high pressure and temperature to sterile the FW and converts it into a fiber-like material (40).

Thermally assisted bio-drying was the lowest rated technology in this study. This is due to the focus of this method that is only to reduce the moisture content of fuel. The CV for this method was only a bit higher than the raw FW. For energy densification criteria, bio-drying performed slightly higher than raw FW and did not really have a significant impact. The process time for this method was also longer than other FW pretreatments.

Overall, the result shows that there is no pre-treatment achieve full total score in this study. The comparison of FW pretreatment methods suggests for torrefaction and HTC to become the main pre-treatment processes for FW. However the initial cost and other research gap need to be filled to understand and increase public awareness of the FW valorization and its impact on the environment if FW is not properly managed. The other FW pretreatment technologies can still challenge this study's results with better upgrade and more development and optimize real potential of these technologies.

\section{Conclusions and suggestion}

Various pre-treatment methods can be used to enhance the properties of FW by significantly reducing smell pollutants and toxic gas emission, reducing slag formation, reducing FW acidity, converting FW into high energy density fuel, enhancing FW heating value, and decreasing its moisture content. Better understanding of the FW pre-treatment methods with the respective type of $\mathrm{FW}$, FW source, and its composition is required to select the best pre-treatment method accordingly. Normally, heating value is one of the most important factors to consider for the selection of the most suitable pre-treatment method. However, the emission of fuel gas, slag formation, and energy density are also important for a sustainable and better future. Autoclaving and leaching scored higher for the reduction in chemicals/ items from $\mathrm{FW}$, which is good for the environment. Nevertheless, leaching is much cheaper and easier than autoclave method.

By comparing all these technologies, the leaching pretreatment technology is a less explored method for FW pretreatment process. The chemical reaction of water with FW can impact the changes in the chemical composition of FW. The changes in chemical composition of FW can produce cleaner flue gas emission and reduce slag tendencies. Pre-treatment of FW can also assist WTE to reduce its erosion problem and increase the energy production. It is recommended that leaching technology can be coupled with any other chemicals such as acid and other pre-treatment technologies to enhance its potential for better FW fuel production. The combination of FW pre-treatments, which includes torrefaction, leaching, and palletization, can easily obtain maximum scores for this study assessment as per Table 7 .

Furthermore, more pre-treatment methods can be integrated and combined into one system to solve the FW problems and management issues, therefore increasing the pre-treatment product value. Energy, Environment, and Economic (3E) assessment and Life Cycle Assessment (LCA) method can also be used to compare the best FW pre-treatment integration method to ensure the valorization of energy from FW is optimized and becomes impactful in the future.

Currently, most of the incinerators do not have any FW pretreatment system. This is due to the additional cost, which is required in the value enhancement process. The increasing cost of FW pre-treatment can be compensated by the increase in efficiency and its energy density enhancement. Pre-treatment of FW can become a future technology for sustainable waste management, especially for WTE incineration. Since the generation of FW increases every year with the increasing global population and many other factors, now is the best time to consider the benefits of treated FW and its value improvement.

\section{Acknowledgments}

The author would like to acknowledge TNB Research Sdn Bhd (TNBR) and Universiti Kebangsaan Malaysia (UKM) for research funding. 


\section{Ethical issue}

Authors are aware of, and comply with, best practice in publication ethics specifically with regard to authorship (avoidance of guest authorship), dual submission, manipulation of figures, competing interests and compliance with policies on research ethics. Authors adhere to publication requirements that submitted work is original and has not been published elsewhere in any language.

\section{Competing interests}

The authors declare that there is no conflict of interest that would prejudice the impartiality of this scientific work.

\section{Authors' contribution}

All authors of this study have a complete contribution for data collection, data analyses and manuscript writing.

\section{References}

1. Congress I. Gustavsson J. et all 2(2011)Global Food Losses and Food Waste Extent, Causes and Prevention.

2. Girotto F, Alibardi L, Cossu R. Food waste generation and industrial uses: A review. Waste Manag [Internet]. 2015;45:32-41. Available from: http://dx.doi.org/10.1016/j.wasman.2015.06.008

3. FAO. Food loss prevention in perishable crops - I [Internet]. FAO Corporate Document Repository. 1981. 27 p. Available from: http://www.fao.org/docrep/s8620e/S8620E04.htm

4. Chu MM. Generating more waste than ever. The Star [Internet]. 2019 Jul 30;https://www.thestar.com.my/news/nation/2019/07/30/. Available

from: https://www.thestar.com.my/news/nation/2019/07/30/generatingmore-waste-than-ever

5. Periathamby A, Hamid FS, Khidzir K. Evolution of solid waste management in Malaysia: Impacts and implications of the solid waste bill, 2007. J Mater Cycles Waste Manag. 2009;11(2):96-103.

6. Pauze M, Mohamad BIN. Plastic waste composition \& Solid waste Generation in Malaysia. Hotel Royale Chulan Damansara, Selangor, Malaysia: Waste Management Association Malaysia (WMAM); 2019. p. 10.

7. Tan S, Hashim H, Lee C, Taib MR, Yan J. Economical and environmental impact of waste-T o-energy (WTE) alternatives for waste incineration, landfill and anaerobic digestion. Energy Procedia [Internet]. 2014:61:704-8. Available from: http://dx.doi.org/10.1016/j.egypro.2014.11.947

8. Rahman HA. Incinerator In Malaysia: Really Needs? Int J Chem Environ Biol Sci. 2013;1(4):678-81.

9. AlQattan N, Acheampong M, Jaward FM, Ertem FC, Vijayakumar N, Bello T. Reviewing the potential of Waste-to-Energy (WTE) technologies for Sustainable Development Goal (SDG) numbers seven and eleven. Renew Energy Focus [Internet]. 2018;27(00):97110. Available from: https://doi.org/10.1016/j.ref.2018.09.005

10. Moult JA, Allan SR, Hewitt CN, Berners-Lee M. Greenhouse gas emissions of food waste disposal options for UK retailers. Food Policy [Internet]. 2018;77(November 2017):50-8. Available from: https://doi.org/10.1016/j.foodpol.2018.04.003

11. Pahla G, Ntuli F, Muzenda E. Torrefaction of landfill food waste for possible application in biomass co-firing. Waste Manag [Internet]. 2018;71(2017):512-20. Available from: https://doi.org/10.1016/j.wasman.2017.10.035

12. Tan ST, Hashim H, Lim JS, Ho WS, Lee CT, Yan J. Energy and emissions benefits of renewable energy derived from municipal solid waste: Analysis of a low carbon scenario in Malaysia. Appl Energy [Internet]. 2014;136:797-804. Available from: http://dx.doi.org/10.1016/j.apenergy.2014.06.003

13. Gao A, Tian Z, Wang Z, Wennersten R, Sun Q. Comparison between the Technologies for Food Waste Treatment. Energy Procedia [Internet]. 2017;105:3915-21. Available from: http://dx.doi.org/10.1016/j.egypro.2017.03.811

14. Ayodele TR, Ogunjuyigbe ASO, Alao MA. Life cycle assessment of waste-to-energy (WtE) technologies for electricity generation using municipal solid waste in Nigeria. Appl Energy [Internet] 2017;201:200-18. Available from: http://dx.doi.org/10.1016/j.apenergy.2017.05.097

15. Mes TZD De, Stams AJM, Reith JH, Zeeman G. Methane production by anaerobic digestion of wastewater and solid.

16. Ma J, Zhang L, Mu L, Zhu K, Li A. Thermally assisted bio-drying of food waste: Synergistic enhancement and energetic evaluation Waste Manag [Internet]. 2018;80:327-38. Available from: https://doi.org/10.1016/j.wasman.2018.09.023

17. Hajinezhad A, Halimehjani EZ, Tahani M. Utilization of RefuseDerived Fuel (RDF) from Urban Waste as an Alternative Fuel for Cement Factory: a Case Study. Int J Renew ENERGY Res EZHalimehjani al. 2016;6(2)

18. Budiman A, Budhijanto W, Pradana YS, Majid AI, Sudibyo H, Deendarlianto. Technological Evaluation of Municipal Solid Waste Management System in Indonesia. Energy Procedia [Internet] 2017;105:263-9. Available from: http://dx.doi.org/10.1016/j.egypro.2017.03.312

19. Moh YC, Manaf LA. Resources, Conservation and Recycling Overview of household solid waste recycling policy status and challenges in Malaysia. "Resources, Conserv Recycl [Internet] 2014;82:50-61. Available from: http://dx.doi.org/10.1016/j.resconrec.2013.11.004

20. Leckner B. Process aspects in combustion and gasification Waste-toEnergy (WtE) units. Waste Manag [Internet]. 2015;37:13-25 Available from: http://dx.doi.org/10.1016/j.wasman.2014.04.019

21. Moora H, Roos I, Kask U, Kask L, Ounapuu K. Determination of biomass content in combusted municipal waste and associated $\mathrm{CO} 2$ emissions in Estonia. Energy Procedia [Internet]. 2017;128:222-9. Available from: https://doi.org/10.1016/j.egypro.2017.09.059

22. Zhang D, Huang G, Xu Y, Gong Q. Waste-to-energy in China: Key challenges and opportunities. Energies. 2015;8(12):14182-96.

23. Tong $\mathrm{H}$, Shen $\mathrm{Y}$, Zhang J, Wang $\mathrm{CH}$, Ge TS, Tong YW. A comparative life cycle assessment on four waste-to-energy scenarios for food waste generated in eateries. Appl Energy [Internet] 2018;225(May):1143-57. Available from: https://doi.org/10.1016/j.apenergy.2018.05.062

24. Sovacool BK, Drupady IM. Innovation in the Malaysian Waste-toEnergy Sector: Applications with Global Potential. Electr J. 2011;24(5):29-41.

25. Chien Bong CP, Ho WS, Hashim H, Lim JS, Ho CS, Peng Tan WS, et al. Review on the renewable energy and solid waste management policies towards biogas development in Malaysia. Renew Sustain Energy Rev [Internet]. 2017;70(July 2015):988-98. Available from: http://dx.doi.org/10.1016/j.rser.2016.12.004

26. Tong H, Yao Z, Lim JW, Mao L, Zhang J, Ge TS, et al. Harvest green energy through energy recovery from waste: A technology review and an assessment of Singapore. Renew Sustain Energy Rev [Internet]. 2018;98(September 2017):163-78. Available from: https://doi.org/10.1016/j.rser.2018.09.009

27. Beyene HD, Werkneh AA, Ambaye TG. Current updates on waste to energy (WtE) technologies: a review. Renew Energy Focus [Internet]. 2018;24(March):1-11. Available from: http://dx.doi.org/10.1016/j.ref.2017.11.001

28. Abdul Samad NAF, Jamin NA, Saleh S. Torrefaction of Municipal Solid Waste in Malaysia. Energy Procedia [Internet]. 2017;138:3138. Available from: https://doi.org/10.1016/j.egypro.2017.10.106

29. Poudel J, Ohm TI, Oh SC. A study on torrefaction of food waste. Fuel [Internet]. 2015;140:275-81. Available from: http://dx.doi.org/10.1016/j.fuel.2014.09.120

30. Huang J, Qiao Y, Wei X, Zhou J, Yu Y, Xu M. Effect of torrefaction on steam gasification of starchy food waste. Fuel. 2019;253(March):1556-64. 
31. Kaushik R, Parshetti GK, Liu Z, Balasubramanian R. Enzymeassisted hydrothermal treatment of food waste for co-production of hydrochar and bio-oil. Bioresour Technol [Internet]. 2014;168:26774. Available from: http://dx.doi.org/10.1016/j.biortech.2014.03.022

32. Wang T, Zhai Y, Zhu Y, Gan X, Zheng L, Peng C, et al. Evaluation of the clean characteristics and combustion behavior of hydrochar derived from food waste towards solid biofuel production. Bioresour Technol [Internet]. 2018;266(May):275-83. Available from: https://doi.org/10.1016/j.biortech.2018.06.093

33. Li L, Diederick R, Flora JRV, Berge ND. Hydrothermal carbonization of food waste and associated packaging materials for energy source generation. Waste Manag [Internet]. 2013;33(11):2478-92. Available from: http://dx.doi.org/10.1016/j.wasman.2013.05.025

34. Sarc R, Lorber KE. Production, quality and quality assurance of Refuse Derived Fuels ( RDFs ). Waste Manag [Internet]. 2013;33(9):1825-34. Available http://dx.doi.org/10.1016/j.wasman.2013.05.004

35. Gendebien A, Leavens A, Black more K, Godley A, Lewin K, Whiting KJ, et al. Refuse derived fuel, current practice and perspectives. Final report. Curr Pract [Internet]. 2003;(July). Available from: http://bases.bireme.br/cgibin/wxislind.exe/iah/online/?IsisScript=iah/iah.xis\&amp; $\mathrm{src}=$ google \&amp;base=REPIDISCA\&amp;lang=p\&amp;nextAction=lnk\&amp ;exprSearch=33505\&amp;indexSearch=ID

36. Chang CC, Chen YH, Lin YS, Hung ZS, Yuan MH, Chang CY, et al. A pilot plant study on the autoclaving of food wastes for resource recovery and reutilization. Sustain. 2018;10(10):1-14.

37. Piao G, Aono S, Mori S, Deguchi S, Fujima Y, Kondoh M, et al. Combustion of refuse derived fuel in a fluidized bed. 1999;18(1998):509-12.

38. Anca-couce A, Brunner T, Kanzian W, Obernberger I, Trattner K. Characterization and condensation behaviour of gravimetric tars produced during spruce torrefaction. J Anal Appl Pyrolysis [Internet]. 2016;119:173-9. Available from: http://dx.doi.org/10.1016/j.jaap.2016.02.020

39. Chen W, Liu S, Juang T, Tsai C, Zhuang Y. Characterization of solid and liquid products from bamboo torrefaction q. Appl Energy [Internet]. 2015;160:829-35. Available from: http://dx.doi.org/10.1016/j.apenergy.2015.03.022

40. Ibrahim N, Yusoff D, Aziz H. Food Waste Characteristics after Autoclaving Treatment. ... Biotechnol Food Sci ... [Internet]. 2011;7:54-7. Available from: http://www.ipcbee.com/vol7/13 ICBFS2011S055.pdf

41. Pham TPT, Kaushik R, Parshetti GK, Mahmood R, Balasubramanian R. Food waste-to-energy conversion technologies: Current status and future directions. Waste Manag [Internet]. 2015;38(1):399-408. Available from: http://dx.doi.org/10.1016/j.wasman.2014.12.004

42. Fakkaew K, Koottatep T, Polprasert C. Effects of hydrolysis and carbonization reactions on hydrochar production. Bioresour Technol [Internet]. 2015;192:328-34. Available from: http://dx.doi.org/10.1016/j.biortech.2015.05.091

43. Chen X, Ma X, Peng X, Lin Y, Yao Z. Conversion of sweet potato waste to solid fuel via hydrothermal carbonization. Bioresour Technol [Internet]. 2018;249(381):900-7. Available from: https://doi.org/10.1016/j.biortech.2017.10.096

44. Novianti S, Nurdiawati A, Zaini IN, Prawisudha P, Sumida H, Yoshikawa K. Low-potassium Fuel Production from Empty Fruit Bunches by Hydrothermal Treatment Processing and Water Leaching. Energy Procedia [Internet]. 2015;75:584-9. Available from: http://dx.doi.org/10.1016/j.egypro.2015.07.460

45. Vassilev S V., Baxter D, Andersen LK, Vassileva CG. An overview of the chemical composition of biomass. Fuel [Internet]. 2010;89(5):913-33. Available from: http://dx.doi.org/10.1016/j.fuel.2009.10.022

46. Niu Y, Tan H, Hui S. Ash-related issues during biomass combustion: Alkali-induced slagging, silicate melt-induced slagging (ash fusion), agglomeration, corrosion, ash utilization, and related countermeasures. Prog Energy Combust Sci [Internet]. 2016;52:161. Available from: http://dx.doi.org/10.1016/j.pecs.2015.09.003

47. Subramani A, Jayanti S. On the occurrence of two-stage combustion in alkali metals. Combust Flame [Internet]. 2011;158(5):1000-7. Available http://dx.doi.org/10.1016/j.combustflame.2011.01.023

48. Wu D, Wang YY, Wang YY, Li S, Wei X. Release of alkali metals during co-firing biomass and coal. Renew Energy [Internet]. 2016;96:91-7. Available http://dx.doi.org/10.1016/j.renene.2016.04.047

49. Zhang J, Han CL, Yan Z, Liu K, Xu Y, Sheng CD, et al. The varying characterization of alkali metals $(\mathrm{Na}, \mathrm{K})$ from coal during the initial stage of coal combustion. Energy and Fuels. 2001;15(4):786-93.

50. Arena U, Di F. Gasification of a solid recovered fuel in a pilot scale fluidized bed reactor. Fuel [Internet]. 2014;117:528-36. Available from: http://dx.doi.org/10.1016/j.fuel.2013.09.044

51. Gillespie GD, Everard CD, Fagan CC, McDonnell KP. Prediction of quality parameters of biomass pellets from proximate and ultimate analysis. Fuel [Internet]. 2013;111:771-7. Available from: http://dx.doi.org/10.1016/j.fuel.2013.05.002

52. Novianti S, Zaini IN, Nurdiawati A, Yoshikawa K. Low Potassium Content Pellet Production by Hydrothermal-Washing Co-treatment. Int J Chem Chem Eng Syst. 2016;1:28-38.

53. Resource Futures. Material bulk densities. wrap Mater Chang a better Environ [Internet]. 2010;ROT039(January 2010):13. Available from: http://www2.wrap.org.uk/downloads/Bulk_Density_Summary_Rep ort_-

_Jan2010.cd53525b.8525.pdf\%0Ahttp://www.wrap.org.uk/sites/file s/wrap/Bulk Density Summary Report - Jan2010.pdf

54. Yuan J, Li Y, Wang G, Zhang D, Shen Y, Ma R, et al. Biodrying performance and combustion characteristics related to bulking agen amendments during kitchen waste biodrying. Bioresour Technol [Internet]. 2019;284(January):56-64. Available from: https://doi.org/10.1016/j.biortech.2019.03.115

55. Nhuchhen D, Basu P, Acharya B. A Comprehensive Review on Biomass Torrefaction. Int J Renew Energy Biofuels. 2014;2014:156.

56. Białowiec A, Micuda M, Koziel JA. Waste to carbon: Densification of torrefied refuse-derived fuel. Energies. 2018;11(11).

57. Mohammed M, Ozbay I, Karademir A, Isleyen M. Pre-treatment and utilization of food waste as energy source by bio-drying process Energy Procedia [Internet]. 2017;128:100-7. Available from: https://doi.org/10.1016/j.egypro.2017.09.021

58. Lu L, Namioka T, Yoshikawa K. Effects of hydrothermal treatment on characteristics and combustion behaviors of municipal solid wastes. Appl Energy [Internet]. 2011;88(11):3659-64. Available from: http://dx.doi.org/10.1016/j.apenergy.2011.04.022

59. Chew KW, Chia SR, Yap YJ, Ling TC, Tao Y, Show PL. Densification of food waste compost: Effects of moisture content and dairy powder waste additives on pellet quality. Process Saf Environ Prot [Internet]. 2018;116:780-6. Available from: https://doi.org/10.1016/j.psep.2018.03.016

60. Demirbas A. Combustion characteristics of different biomass fuels. Prog Energy Combust Sci. 2004;30(2):219-30.

61. Lim M, Zulkifli AZS, Hassan H. Biomass combustion: Potassium and sodium flame emission spectra and composition in ash. Nihon Enerugi Gakkaishi/Journal Japan Inst Energy. 2017;96(9):367-71.

62. Shoulaifar TK, Demartini N, Zevenhoven M, Verhoe F, Kiel J. AshForming Matter in Torre fi ed Birch Wood: Changes in Chemical Association. 2013;

63. RedCorn R, Fatemi S, Engelberth AS. Comparing End-Use Potential for Industrial Food-Waste Sources. Engineering [Internet]. 2018;4(3):371-80. Available from: https://doi.org/10.1016/j.eng.2018.05.010 